\title{
The Influence of Organizational Culture, Motivation and Job Satisfaction on Teacher Performance at Bina Insan Mandiri Vocational High School
}

\author{
Muhajir Ahmad ${ }^{1}$, Bayudhirgantara Emanuel ${ }^{2}$ \\ \{ahmadmuhajir8410@gmail.com ${ }^{1}$, bayudhirgantara1@gmail.com² ${ }^{2}$ g \\ Mercubuana University, Jakarta, Indonesia ${ }^{12}$
}

\begin{abstract}
Improving teacher performance in an organization or especially in schools is very necessary to be able to produce good performance. The purpose of writing this journal is to determine the factors that can affect teacher performance, where the authors limit the factors of organizational culture, motivation and job satisfaction of teachers at SMK Bina Insan Mandiri. The method in this research is a descriptive method with a quantitative approach (deductive). The subject of this research is Bina Insan Mandiri Vocational High School. The population in this study were the principal, the vice principal in the curriculum sector, the vice principal for student affairs and finally the teachers at the school, with the total population in this study amounting to 67 people. Determination of the number of samples using saturated samples, data collection techniques using observation, questionnaires and documentation, while data analysis techniques using parametric statistical tests. Hypothesis testing is done by interpreting the results of the linear regression test. Based on the results of the analysis of funding calculations, it can be concluded that organizational culture, motivation and job satisfaction both independently and simultaneously have a positive and significant effect on the performance of the Bina Insan Mandiri Vocational High School teachers. That is, the better the organizational culture, motivation and job satisfaction of the teacher, the better the teacher's performance towards the Bina Insan Mandiri Vocational High School.
\end{abstract}

Keywords: Organizational Culture, Work Motivation, Job Satisfaction, Performance and Teachers

\section{Introduction}

Education is a conscious and planned effort to create an atmosphere of learning and the learning process in such a way that students can actively develop their potential, have selfcontrol, intelligence, skills in society, religious spiritual strength, personality and noble morals [1]. The meaning contained in the law is to achieve the stated goals, the learning process must be carefully planned so that students can develop their potential. Education is a human effort to broaden their knowledge in order to shape attitudes and behavior and character towards a better direction [2]. As an effort that not only yields great benefits, education is also part of some of the basic human needs which are often felt to have not met expectations. This is evident from the fact that there are still many formal education 
graduates who have not been able to meet the criteria for job opportunities as a reflection of the mastery of knowledge they have obtained from educational institutions [2].

The teacher is a person who is directly involved in the learning process, is at the forefront and has a central position in the process of developing students, for that the ability of students will depend on the personal abilities or performance possessed by a teacher in carrying out their duties [3]. The teacher has the responsibility as a determinant of the quality of the output of students [4]. Any efforts and programs carried out in order to improve the quality of education will not be successful if there is no support from professional teachers $[4]$.

Based on the results of the teacher supervision assessment carried out by the principal, the performance of teachers at Bina Insan Mandiri Vocational High School looks fluctuating, namely an increase and decrease every year. The following is the supervision data of Bina Insan Mandiri Vocational High School teachers for the last 3 years:

Table 1. Data on Supervision of Bina Insan Mandiri Vocational High School Teachers

\begin{tabular}{l|c|c|c}
\hline \multirow{2}{*}{\multicolumn{1}{c|}{ Score }} & \multicolumn{3}{|c}{ Year } \\
\cline { 2 - 4 } & $2015-2016$ & $2016-2017$ & $2017-2018$ \\
\hline Very Good & $19 \%$ & $37 \%$ & $28 \%$ \\
\hline Well & $65 \%$ & $51 \%$ & $56 \%$ \\
\hline Enough & $16 \%$ & $12 \%$ & $14 \%$ \\
\hline
\end{tabular}

Source: Author processed, 2019

Based on table 1. regarding the performance data of SMK BIM teachers from 2016 to 2018, there are still teacher assessments that have increased or decreased. can be seen in table 1. in 2018 there was a decrease in performance appraisal with a very good category of $9 \%$. In the sufficient value category in 2018 , the increase in value is thought to have occurred due to a decrease in the average percentage of teacher performance scores by $2 \%$.

The level of teacher performance can also be seen from the results of student learning achievement [5]. The principle of good performance can be seen from the results obtained from the achievement scores of students [6]. Teachers are the most important component in creating quality human resources in accordance with the noble ideals of the nation as stated in the goals of national education, therefore it is necessary to have professional teachers in the learning process without the professional attitude of an institution such as an action education institution that will get maximum results, in words another teacher is one of the keys to the success of an educational institution. The results of the interviews with the three teachers who had the longest working tenure indicated that the factors suspected of causing a decline in the performance of the BIM SMK teachers. The factors referred to are: a) Teacher competence; b) Work motivation; c) Discipline; d) co-workers; e) Salary; f) Promotion; g) Job satisfaction; h) Work facilities; i) Leadership.

The factors mentioned above are the same as the factors explained by Siagian, which states that performance is updated by salary, work environment, organizational culture, leadership, and work motivation, work discipline, and job satisfaction [7]. Another factor that affects gru's performance is the work environment. The work environment for teachers can be interpreted as a scope or area in developing competence and knowledge, as well as the insights they have to help carry out work activities that lead to increased performance (Betania, 2014). If a teacher has a positive attitude towards his job, it can be ensured that the teacher will carry out his main duties and functions as an educator in schools with full responsibility [8]. 
All organizations that promise to provide the best service, of course, rely heavily on the role and function of human resources as service drivers by playing their functions appropriately and professionally. Therefore, Bina Insan Vocational High School as an educational institution is required to always provide maximum service to stakeholders. To realize this, it requires organizational commitment and teachers in providing services based on high teacher work motivation, excellent teacher job satisfaction and supported by the right organizational culture in independent research and performance as the dependent variable to be examined.

The phenomenon of organizational culture that occurs at Bina Insan Mandiri Vocational High School is not a match between teacher expectations and assigned tasks. So that many teachers still feel a lack of support in innovating for school progress. Not organizational culture, what teachers want but another thing is work motivation. To be able to improve performance and commitment to the school to be able to achieve the school's goals, teachers must be given feedback by the school. Apart from organizational culture (novation and taking risk) and work motivation, another factor that becomes the variable in this study is job satisfaction. Job satisfaction is an important thing in achieving an achievement. If an organization gets to the point where communication within an organization does not feel job satisfaction then the organization will not function as effectively as it should.

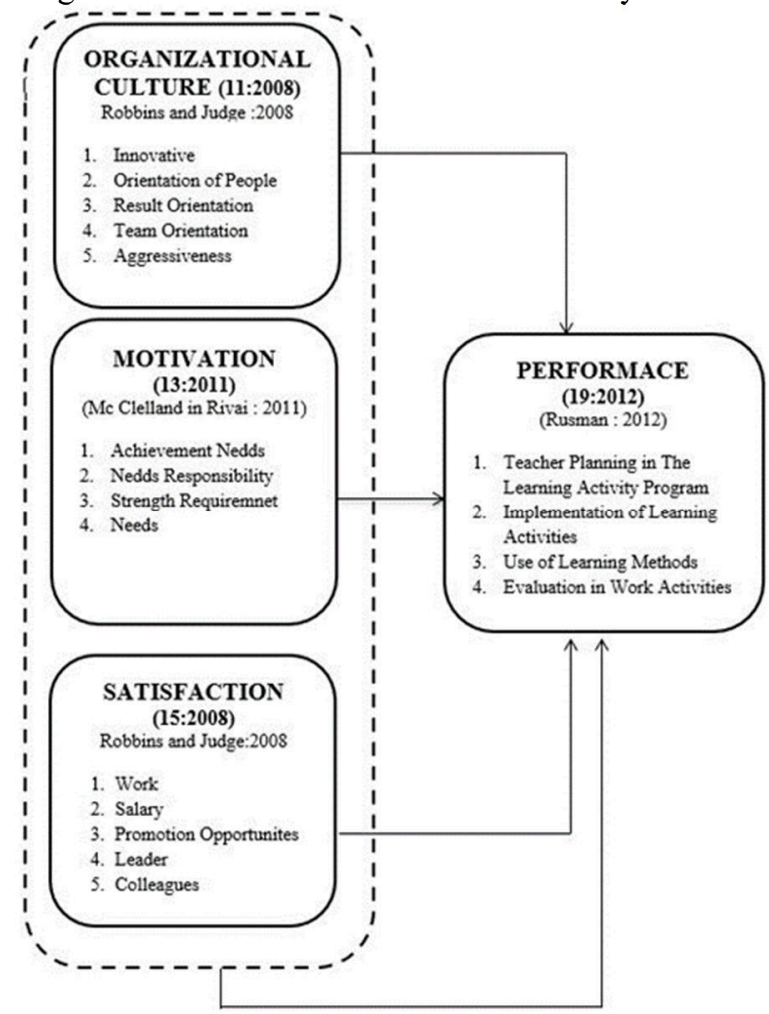

\section{Hypothesis:}

Fig 1. Research Framework (Source: Researcher, 2020)

$\mathrm{H}_{\mathrm{a}}$ There is a positive and significant influence of organizational culture on the performance of the Bina Insan Mandiri Vocational School teachers.

$\mathrm{H}_{\mathrm{o}}$ There is no positive and significant influence of organizational culture on the 
performance of Bina Insan Mandiri Vocational School teachers.

$\mathrm{H}_{\mathrm{a}}$ There is a positive and significant influence of motivation on the performance of the Bina Insam Mandiri Vocational School teachers

$\mathrm{H}_{\mathrm{o}} \quad$ There is no positive and significant influence of motivation on the performance of Bina Insam Mandiri Vocational School teachers

$\mathrm{H}_{\mathrm{a}} \quad$ There is a positive and significant influence of Satisfaction on the performance of the teachers at Bina Insan Mandiri Vocational School

$\mathrm{H}_{\mathrm{o}} \quad$ There is no positive and significant effect of Satisfaction on the performance of the Bina Insan Mandiri Vocational School teachers

$\mathrm{H}_{\mathrm{a}} \quad$ There is a positive and significant influence of organizational culture, motivation and satisfaction on the performance of the Bina Insan Mandiri Vocational School teachers.

$\mathrm{H}_{\mathrm{o}} \quad$ There is no positive and significant influence of organizational culture, motivation and satisfaction on the performance of Bina Insan Mandiri Vocational School teachers.

\section{Research Method}

This research uses a descriptive method. The descriptive method in this study is used to provide an overview of organizational culture, motivation and job satisfaction and to calculate their effects on teacher performance. The type of investigation used in this study is a causal relationship, which is a type of investigation that aims to determine the magnitude of the influence of the independent variable on the dependent variable. The independent variable in this study is organizational culture, motivation and job satisfaction, while the dependent variable is teacher performance.

In this study, researchers used a quantitative (deductive) approach. The quantitative approach is an attempt to measure the variables in the study (variable $\mathrm{X}$ and variable $\mathrm{Y}$ ) to then look for the influence and relationship of the two variables. Furthermore, the subject which is the location of this research is SMK Bina Insan Mandiri. The population in this study were the principal, amounting to 1 person, 1 representative of the principal in the curriculum field, 1 representative of the principal in the field of student affairs and 64 teachers, so that the total population in this study amounted to 67 people. Determination of the number of samples using saturated samples, namely the entire population is used as the research sample. Data collection techniques used observation, questionnaires and documentation, while data analysis techniques used parametric statistical tests.

Hypothesis testing is done by interpreting the results of the linear regression test. The testing mechanism is carried out by comparing the significance value of the calculation results with a significance number (probability) of 0.05 . Decisions are taken using the criteria "if the count of significance $<0.05$; then $\mathrm{Ha}$ is accepted ', and "if the count of significance $>0.05$; then $\mathrm{H} 0$ is rejected.

\section{Results and Discussion}

3.1 Hypothesis Test Results

Hypothesis testing to determine the effect of organizational culture, motivation and job satisfaction on teacher performance is correlation test, simple multiple regression test and 
determination test. The three statistical tests are carried out so that researchers can interpret the data obtained during the study into the information needed to answer the problem formulation. The following is the calculation result of statistical tests using SPSS 21 software.

Table 2. Data Comparison of Hypothesis Test Results

\begin{tabular}{lllrrrr}
\hline No & Aspect & R & R Square & \multicolumn{1}{c}{ Sig. F } & $\mathrm{T}_{\text {Count }}$ & $\mathrm{T}_{\text {Table }}$ \\
\hline 1 & $\mathrm{X}_{1}-\mathrm{Y}$ & 0,351 & 0,123 & 0,001 & 3,312 & 1,992 \\
2 & $\mathrm{X}_{2}-\mathrm{Y}$ & 0,679 & 0,461 & 0,000 & 8,174 & 1,992 \\
3 & $\mathrm{X}_{3}-\mathrm{Y}$ & 0,731 & 0,535 & 0,000 & 9,473 & 1,992 \\
4 & $\mathrm{X}_{1}, \mathrm{X}_{2}, \mathrm{X}_{3}-\mathrm{Y}$ & 0,671 & 0,658 & 0,000 & 5.606 & 1,992 \\
\hline
\end{tabular}

Source: Research Results, (2020)

\subsection{Analysis of the Influence of Organizational Culture on Teacher Performance at Bina Insan Mandiri Vocational High School}

The results of linear regression testing between organizational culture variables and teacher performance at Bina Insan Mandiri Vocational High School, obtained a correlation coefficient $(\mathrm{R})$ or a relationship of $35.1 \%$, and its contribution ( $\mathrm{R}$ Square) is $12.3 \%$, a significance level of 0.001 , and the results $\mathrm{T}$-count of 3,312 is greater than $\mathrm{T}$-table of 1,992 . Based on the test results, it can be concluded that $\mathrm{H}_{\mathrm{a}}$ is accepted and $\mathrm{H}_{0}$ is rejected, which means that organizational culture variables have a positive and significant effect on teacher performance at Bina Insan Mandiri Vocational High School. The relationship between organizational culture variables and teacher performance based on the results of this calculation is categorized as weak, while the contribution of organizational culture variables to teacher performance is categorized as very weak. The organizational culture inherent in Bina Insan Mandiri SMK teachers is still not good, one of which is the habit of teachers being late in working hours. This of course greatly affects teacher performance, because it has become a habit, making teachers not deterred from repeating these bad habits, so that teacher performance is classified as low.

In order for the organizational culture in these schools to change, school management needs to be improved. Supervision by the principal as the manager as well as the leader in the school must control and evaluate the organizational culture that is used to running in the school. Changes in organizational culture need to be carried out considering that it will affect grub performance, especially performance in the implementation of learning and which will ultimately have an impact on students. The teacher is a role model for students, students will follow the habits of their teachers, so that the habit of being late for work that is usually done by teachers will have a negative impact on students, namely by following late school hours. The performance performed by a teacher arises because of the command discipline and selfimposed discipline [12]. Command discipline is the discipline that is ordered. That is, discipline that comes from a recognized power to obtain implementation through regulations or culture that exist within the organization. If the organizational culture is weak, it will be easy to form groups as opposed to the organization [9].

In the performance of teacher discipline, indicators of organizational culture will be met, such as result orientation, orientation towards people, orientation to the team [13]. With the result orientation and people, it is necessary to implement norms, so every teacher will implement the existing norms or regulations in SMK Bina Insan Mandiri such as coming and coming home from work on time, so that the effective performance of teachers is achieved. 
With the implementation of values, each teacher will apply the values that exist in the Bina Insan Mandiri Vocational School such as honesty, assertiveness to discipline. Trust and philosophy will make teachers feel confident in the organization and will do anything for the organization, such as doing work and complying with existing regulations. This is consistent with previous research conducted by Hendiyana entitled "The effect of competence and work motivation on teacher job satisfaction and its impact on teacher performance (Bogor Regency Vocational School Study) shows that there is a positive and significant influence between organizational culture and performance [14].

\subsection{Analysis of the Effect of Work Motivation on Teacher Performance at Bina Insan Mandiri Vocational High School}

The results of linear regression testing between work motivation variables and teacher performance at Bina Insan Mandiri Vocational High School, obtained a correlation coefficient $(\mathrm{R})$ or a relationship of $67.9 \%$, and a contribution (R Square) of $46.1 \%$, significance at the level of 0.000 , and the results $\mathrm{T}$-count of 8.174 is greater than $\mathrm{T}$-table of 1.992. Based on the test results, it can be concluded that $\mathrm{H}_{\mathrm{a}}$ is accepted and $\mathrm{H}_{0}$ is rejected, which means that the work motivation variable has a positive and significant effect on the performance of teachers at Bina Insan Mandiri Vocational High School.

The relationship between work motivation variables and teacher performance based on the results of this calculation is categorized as strong, while the contribution of work motivation variables to teacher performance is in the medium category. The work motivation of the teachers at Bina Insan Mandiri Vocational High School is already good, even though it is inversely proportional to the organizational culture at the school. Teachers at Bina Insan Mandiri Vocational High School are highly motivated if there are several activities aimed at developing their competence, including MGMP deliberations, technical guidance (Bimtek), and education and training to improve other pedagogical competencies.

High motivation does not require external rewards, it encourages people to reflect the ratio in their behavior and master themselves so that they show good performance because they require high awareness from teachers [15]. Good teacher performance will be created when work motivation indicators are met, such as the need for achievement (need for achievement), need for affiliation, need for power (need for power) [16]. With the need for achievement (need for achievement), every teacher at Bina Insan Mandiri Vocational High School will try to get an award or achievement in the school, so that the teacher will try to show his best ability to get an award or achievement. One of them is by obeying the rules at school, so that it will create high performance.

The need for affiliation will encourage teachers at the Bina Insan Mandiri Vocational High School to interact more with their colleagues. So that teachers will feel comfortable and at home in school because of the familiarity or good relationship between fellow teachers. This will reduce truancy during working hours. The need for power will push, which is a spontaneous response to a capable leader and is an impulse in itself or called motivation. This is in accordance with previous research conducted by Munandar entitled "The influence of work environment, motivation and job satisfaction on the performance of Madrasah Aliyah teachers in Banyumas Regency, indicating that there is a positive and significant influence between work environment, work motivation and job satisfaction on teacher performance. [17]. 


\subsection{Analysis of the Effect of Work Motivation on Teacher Performance at Bina Insan Mandiri Vocational High School}

The results of linear regression testing between job satisfaction variables and teacher performance at Bina Insan Mandiri Vocational High School, obtained a correlation coefficient (R) or a relationship of $73.1 \%$, and its contribution (R Square) is $53.5 \%$, a significance level of 0.000 , and the results $\mathrm{T}$-count of 9.473 is greater than $\mathrm{T}$-table of 1.992 . Based on the test results, it can be concluded that $\mathrm{H}_{\mathrm{a}}$ is accepted and $\mathrm{H}_{0}$ is rejected, which means that the job satisfaction variable has a positive and significant effect on the performance of teachers at Bina Insan Mandiri Vocational High School.

The relationship between job satisfaction variables and teacher performance based on the results of this calculation is categorized as strong, while the contribution of job satisfaction variables to teacher performance is included in the medium category. The job satisfaction received by the teachers at SMK Bina Insan Mandiri is quite good. The job satisfaction received by the teachers at SMK Bina Insan includes them getting from the allowances they receive every month, the conditions and comfort of working at the school, awards for outstanding teachers every year which are usually done by the school, the opportunity to develop their competencies very open, the study tour activities carried out by the school as well as the results of semester exams and even the fairly high results of the national examinations of students affect the performance satisfaction of teachers.

Teacher job satisfaction must be created as best as possible in order to improve the morale, dedication, love and discipline of employees. Job satisfaction greatly affects the level of discipline of teachers later, meaning that if job satisfaction is obtained eating teacher discipline will improve, on the contrary if job satisfaction is less or even not achieved, then teacher discipline will be lower [18]. The teacher's performance will be better if the teacher gets job satisfaction. Good teacher performance can be seen from the way teachers teach, where teacher performance derived from high job satisfaction will affect the high quality of student output. Therefore, the job satisfaction of a teacher must be considered by the school, in order for the teacher's performance to improve [19].

In order to improve the quality of education quality and learning outputs that have a direct impact on students, a school principal is required to improve job satisfaction of teachers and education personnel. Job satisfaction is a psychological aspect that reflects a person's feelings about their job. He will feel satisfied with the match between his abilities, skills and expectations with the job he is facing. Teacher job satisfaction must be considered, because this is one factor in increasing teacher achievement, which will have an impact on efforts to improve and improve the quality of education [18].

3.5 Analysis of the Influence of Organizational Culture, Work Motivation and Job Satisfaction on Teacher Performance at Bina Insan Mandiri Vocational High School

The results of multiple linear regression testing between the variables of organizational culture, motivation and job satisfaction with teacher performance at Bina Insan Mandiri Vocational High School, obtained a correlation coefficient (R) or a relationship of $67.1 \%$, and its contribution (R Square) is $65.8 \%$, significance at the level of 0.000 , and the result of $\mathrm{T}$-count is 5.606 , which is greater than $\mathrm{T}_{\text {-table }}$ of 1.992 . Based on the results of these tests, it can be concluded that $\mathrm{H}_{\mathrm{a}}$ is accepted and $\mathrm{H}_{0}$ is rejected, which means that the variables of organizational culture, motivation and job satisfaction have a positive and significant effect on teacher performance at Bina Insan Mandiri Vocational High School. The relationship between the variables of organizational culture, motivation and job satisfaction with teacher 
performance based on the results of this calculation is categorized as strong, while the contribution of job satisfaction variables to teacher performance is in the strong category.

Good performance is the inner strength of a person which is actualized into an action, attitude or behavior to be willing to obey and obey the rules either from one's own awareness or because of coercion. Good performance is the main reason for obedience and adherence to the boundaries set by the organization both in the form of job descriptions, organizational regulations and work targets [20]. Teacher good performance can be triggered by selfawareness or high motivation from each teacher and from the rules or culture within the school. High work motivation will encourage teachers to do their job as well as possible and minimize errors by performing well by obeying the existing rules in school.

Work motivation is the main thing that triggers a disciplined attitude from the teacher. Every teacher must have a strong motivation when carrying out their duties [4]. On behalf of the principal must be able to help teachers to foster motivation and maintain that motivation within the teacher, such as by giving praise to the teacher for doing a good job [21]. Organizational culture is also a factor affecting teacher work discipline. A strong organizational culture will compel and influence teacher performance. A strong organizational culture will force and influence its members to do something that is ordered or that has become a habit in the organization. In this case the teacher is required to identify himself with the organization, accept the vision and mission of the organization and always want himself to survive to be part of the organization which can encourage someone to act to perform well if the indicators can be maximized.

The way to maximize organizational culture can be done by forming rules in accordance with school goals and teachers need to be encouraged to be involved in following these school rules by introducing these rules thoroughly and comprehensively [22]. The teacher's habit will automatically be created when the teacher is getting used to the existing rules in school with the habit of obeying these rules, it will become a culture that can create high performance. Teachers in this school will feel satisfaction at work if they get appropriate awards, smooth salaries without having to be deducted by the school and are always motivated to always be disciplined with the support of a good work culture as well [3]. The performance of Bina Insan Mandiri Vocational School teachers is influenced by the motivation of the teachers themselves. Job satisfaction obtained by teachers and culture in SMK Bina Insan Mandiri. Teachers who have low motivation and they work in a bad culture tend to show low performance, because they do not have the awareness and drive from themselves to obey the rules and make this behavior a school habit.

Teachers who have high work motivation and work in a conducive work culture and get satisfaction at work tend to show better performance, because they have a high awareness of obeying the rules and are supported by a work culture that requires them to comply with existing school regulations.

\section{Conclusions}

Based on the results of the analysis it can be concluded that organizational culture itself has a positive and significant effect on teacher performance, work motivation has a positive and significant effect on teacher performance, job satisfaction has a positive and significant effect on teacher performance, and organizational culture, motivation and job satisfaction simultaneously have an effect. positive and significant towards the performance of the Bina Insan Mandiri Vocational School Teachers. 


\section{References}

[1] Undang-Undang Republik Idonesia Nomor 20 Tahun 2013 Tentang Sistem Pendidikan Nasional

[2] Silaban, Rafuddin. (2015). Hubungan Motivasi Kerja Dengan Kinerja Guru Pada Sekolah Dasar Negeri Kecamatan Medan Petisah Medan. Jurnal Ilmiah Politeknik Mandiri Bina Prestasi. Vol. 4, No. 2.

[3] Sobirin. (2018). Faktor-Faktor Yang Mempengaruhi Kinerja Mengajar Guru Sekolah Dasar", Jurnal Adminisistrasi Pendidikan. Vol. 14, No.1.

[4] Sunhaji. (2014). Kualitas Sumber Daya Manusia (Kualifikasi, Kompetensi dan Sertifikasi Guru. Jurnal Kependidikan. Vol. 2, No. 1.

[5] Eliyanto. (2018). Pengaruh Motivasi Kerja dan Lingkungan Kerja Terhadap Kinerja Guru SMA Muhammadiyah di Kabupaten Kebumen. Jurnal Pendidikan Madrasa. Vol. 3, No.1.

[6] Hairuddin, Arminas, et al (2016). Motivation, Competence and Organizational Commitmen's Effect on Lecture's Job Satisfaction and Lecturers Performance.IRA -International Journal Of Management \& Sosial Science. Vol .06, No. 04.

[7] Siagian, P Sondang. (2012). Manajemen Sumber Daya Manusia. Jakarta; Bumi Aksara.

[8] Zainal, Aqib. (2002). Profesionalisme Guru dalam Pembelajaran. Surabaya: Insan.

[9] Robbins, Stephen and Hudge. (2008). Prilaku Organisasi (Oraganizational Behavivior). Jakarta; Salemba Empat.

[10] Rivai, Veithzal dan Ella Sagala. (2011). Manajemen Sumber Daya Manusia. Cet. Ke-1. Jakarta: Rajawali Pers.

[11] Rusman. (2012). Model - Model Pembelajaran. Depok: PT Rajagrafindo Persada.

[12] Sari, Pratiwi Indah. (2018). Pengaruh Lingkungan Kerja Dan Motivasi Kerja Terhadap Kinerja Guru Smk Negeri 10 Muaro Jambi. Jurnal Eklektik : Jurnal Pendidikan Ekonomi dan Kewirausahaan. Vol. 1, No.1.

[13] Pangarso, Astadi dan Vidi Ramadhyanti. (2015). Pengaruh Lingkungan Kerja Non Fisik Terhadap Kepuasan Kerja Dosen Tetap Studi Pada Fakultas Komunikasi Dan Bisnis Universitas Telkom Bandung” Jurnal Kinerja. Vol. 19, No.1.

[14] Hendriyana, Indra. (2019). Pengaruh Kompetensi dan Motivasi Kerja Terhadap Kepuasan Kerja Guru dan Dampaknya Terhadap Kinerja Guru SMK XYZ Kabupaten Bogor. Tesis. Jakarta: Universitas Mercubuana.

[15] Winardi. (2009). Teori Organisasi dan Pengorganisasian. Jakarta: Rajawali Pers.

[16] Hasibuan. (2010). Manajemen Sumber Daya Manusia. Jakarta: PT Bumi Aksara.

[17] Munandar, Aji. (2019). Pengaruh Lingkungan Kerja, Motivasi Kerja dan Kepuasan Kerja Terhadap Kinerja Guru Madrasah Aliyah Di Kabupaten Banyumas. Tesis. Program Studi Manajemen Pendidikan Islam, Institut Agama Islam Negeri Purwokerto.

[18] Rusydiati. (2017). Kepuasan Kerja Guru Terhadap Prestasi Kerja Guru Dalam Meningkatkan Mutu Pendidikan Di Madrasah. Studia Didaktika. Vol. 11, No.1.

[19] Betania, K, Widya. (2014). Pengaruh Lingkungan Kerja Fisik, Kepuasan Kerja, Dan Disiplin Kerja Terhadap Kinerja Guru Di Smk Pgri 1 Mejobo Kudus. Economic Education Analysis Journal. Vol. 3, No. 2.

[20] Kristanti, Erlina. (2017). Pengaruh Lingkungan Kerja Fisik dan Lingkungan Kerja Non Fisik Terhadap Stres Kerja Dan Dampaknya Terhadap Kinerja. Jurnal Ilmu Manajemen. Vol. 5, No. 1.

[21] Firmawati. "Pengaruh Kepemimpinan Kepala Sekolah Dan Motivasi Kerja Terhadap Kinerja Guru”. Jurnal Magister Administrasi Pendidikan Pascasarjana Universitas Syiah Kuala. Vol. 5, No. 3

[22] Rifa Elfita, et.al. "Pengaruh Lingkungan Kerja Terhadap Kinerja Guru Pendidikan Agama Islam Di MTs Negeri Sentajo Filial Singingi Kecamatan Singingi Kabupaten Kuantan Singingi. Jurnal Al-Hikmah. Vol. 1, No. 1. 